\title{
Juan de Segovia on the Superiority of Christians over Muslims: Liber de magna auctoritate episcoporum in concilio generali 10.6
}

\author{
Jesse D. Mann
}

No discussion of dialogue between Christians and Muslims in late medieval Europe can overlook the contributions of the Spanish theologian Juan de Segovia (ca. 1393-1458). As is now increasingly well known, especially to those interested in Nicholas of Cusa, Segovia initiated an important correspondence regarding Islam with several prominent churchmen (including Cusa) after the fall of Constantinople in 1453 and subsequently produced the first trilingual Quran (Arabic, Latin, and Castilian), which unfortunately has not come down to us. ${ }^{1}$ Although the Ottoman conquest of the Byzantine capital surely gave new urgency to Segovia's interest in the 'Islamic question,'2 that interest

1 On Segovia, his correspondence pertaining to the 'Islamic question,' and his trilingual Qur'an, see Rudolf Haubst, "Johannes von Segovia im Gespräch mit Nikolaus von Kues und Jean Germain über die göttliche Dreieinigkeit und ihre Verkundigung vor den Mohammedanern," Münchener Theologische Zeitschrift 2 (1951): 115-29; Darío Cabanelas Rodríguez, Juan de Segoviay el problema islámico (Madrid: Universidad de Madrid, 1952); R. W. Southern, Western Views of Islam in the Middle Ages (Cambridge: Harvard University Press, 1962), 86-103; James E. Biechler, "A New Face Toward Islam: Nicholas of Cusa and John of Segovia," in Nicholas of Cusa: In Search of God and Wisdom, ed. Gerald Christianson and Thomas M. Izbicki (New York: Brill, 1991), 185-202; Anne Marie Wolf, Juan de Segovia and Western Perspectives on Islam in the Fifteenth Century (Ph.D. diss., University of Minnesota, 2003); Victor Sanz Santacruz, "Juan de Segovia y Nicolás de Cusa frente al Islam: su comprensíon intelectualista de la fe cristiana," Anuario de Historia de la Iglesia 16 (2007): 181-194; Thomas E. Burman, Reading the Qurān in Latin Christendom, 1140-1560 (Philadelphia: University of Pennsylvania Press, 2009), 178-197; Walter Andreas Euler and Franz-Bernhard Stammkötter, "Johannes von Segovia und Nikolaus von Kues im Gespräch über den Islam," in Cusanus und der Islam, ed. Walter Andreas Euler and Tom Kerger (Trier: Paulinus, 2010), 49-63; and most recently, Juan de Segovia, De gladio divini spiritus in corda mittendo Sarracenorum: Edition und deutsche Übersetzung, ed. Ulli Roth, 2 vols. (Wiesbaden: Harrassowitz, 2012) [hereafter Roth, De gladio].

2 On the significance of the fall of Constantinople, see Erich Meuthen, "Der Fall von Konstantinopel und der lateinische Westen," Mitteilungen und Forschungsbeiträge der Cusanus-Gesellschaft 16 (1984): 35-6o, esp. 58-6o. 
long antedated $1453 \cdot{ }^{3}$ We also know that Segovia and Cusa shared their mutual interest in Islam while they were together at the Council of Basel in the 1430 s. $^{4}$

Until recently, scholarly attention has primarily focused on Segovia's correspondence with Cusa, Jean Germain, and Aeneas Sylvius Piccolomini. ${ }^{5}$ Now, however, scholars are studying and editing Segovia's other writings on Islam, as the work of Ulli Roth attests. ${ }^{6}$ Santiago Madrigal has also rightly observed that even in works seemingly unrelated to Islam, such as his Liber de magna auctoritate episcoporum in concilio generali, Segovia occasionally addresses issues pertaining to Christian-Muslims relations. ${ }^{7}$ Indeed, it is a chapter from this work that concerns us here.

Of course, what has particularly stimulated modern interest in Segovia's views on Islam is his seeming openness to dialogue with Muslims, which he repeatedly calls "the way of peace and doctrine rather than the way of war." Regardless of whether Segovia's dialogic and pacifistic approach to Islam

3 For examples, see Wolf, "Juan de Segovia," 111ff.; Burman, Reading the Qur'an, 179; and Santacruz, "Juan de Segovia," 184. See also Roth, De gladio, 1: xxx-xliii.

4 See Biechler, "A New Face," 189; and Santacruz, "Juan de Segovia," 183.

5 Davide Scotto's recent doctoral thesis (Florence, 2012) on this correspondence, which I was unable to consult for this article, should provide a better textual foundation for further study of this correspondence.

6 See, e.g., Roth's edition cited above (n. 1). See also the recent improved edition of Segovia's prologue to the trilingual Qur’an by Jose Martínez Gázquez, "El Prólogo de Juan de Segobia al Corán (Qur’ān) trilingüe (1456)," Mittellateinisches Jahrbuch 38 (2003): 389-410.

7 Santiago Madrigal Terrazas, "Lex Christi, lex Moysi, lex Machometi: Juan de Segovia y la polémica anti-islámica," in Umbra, imago, veritas: homenaje a los profesores Manuel Gesteira, Eusebio Gil y Antonio Vargas-Machuca, ed. Secundino Castro et al. (Madrid: Universidad Pontificia Comillas, 2004), 339-365; and idem, "Judíos, moros y cristianos: La vision teológica de Juan de Segovia (1393-1458) acerca de las tres culturas ibéricas," in Christlicher NordenMuslimischer Süden: Ansprüche und Wirklichkeiten von Christen, Juden und Muslimen auf der iberischen Halbinsel im Hoch -und Spätmittelalter, ed. Matthias M. Tischler and Alexander Fidora (Münster: Aschendorff, 2011), 489-504. Anne Marie Wolf has also noted this point as evidence of the connection between Segovia's ecclesiological and Islamic writings, see Wolf, "Juan de Segovia," 238-239. According to Rolf De Kegel, the Liber de magna auctoritate (hereafter: $L M A$ ) is the only ecclesiological work in which Segovia discusses Islam. See Rolf De Kegel, ed., Johannes von Segovia, Liber de magna auctoritate episcoporum in concilio generali (Fribourg: Universitätsverlag, 1995), 34.

8 See Wolf, “Juan de Segovia," 222-23; and Biechler, “A New Face," 191. 
derives from Scripture, ${ }^{9}$ from his university background, ${ }^{10}$ from his personal experiences in Spain or Basel, ${ }^{11}$ or from some combination of these factors, this approach has understandably made him attractive to those seeking nonviolent models for Christian-Muslim interaction. As I have argued elsewhere, however, the attractive aspects of Segovia's approach to Islam should not blind us to his ultimate aim, namely the conversion of Muslims to Christianity, ${ }^{12}$ nor to his seemingly longstanding reliance on the traditional and quite negative Western image of Islam and Muslims. ${ }^{13}$

Hence, as Thomas Burman has so ably discussed, Segovia presents us with a fine example of the tension or oscillation experienced by some medieval Christians between hostility toward Islam and a desire to study and understand Islam, or between "polemic and philology."14 While manifest in his work

This is Wolf's argument, see, e.g., her, “Juan de Segovia," iv, 255-257, and idem, "Pleas for Peace, Problems for Historians: A 1455 Letter from Juan de Segovia to Jean Germain on Countering the Threat of Islam," in Religious Conflict and Accommodation in the Early Modern World, ed. Marguerite Ragnow and William D. Phillips, Jr. (University of Minnesota: Center for Early Modern History, 2011), 55-68.

I have myself advanced this view, though not to the exclusion of the others listed here. See Jesse D. Mann, "Truth and Consequences: Juan de Segovia on Islam and Conciliarism," Medieval Encounters 8 (2002): 79-90.

On the Spanish context, see, e.g., Wolf, "Juan de Segovia," esp. chap. 3; idem, "Pleas for Peace," 62-63 (with bibliography); and Gerard Wiegers, Islamic Literature in Spanish and Aljamiado: Yça of Segovia (fl. 1450), His Antecedents and Successors (Leiden: Brill, 1994). Leyla Rouhi's "A Fifteenth-Century Salamancan's Pursuit of Islamic Studies," in Under the Influence: Questioning the Comparative in Medieval Castile, ed. Cynthia Robinson and Leyla Rouhi (Leiden: Brill, 2004), 21-42 is an interesting, but ultimately unconvincing attempt to apply a postmodern analysis to the collaboration between Segovia and Yça Gidelli. For relevant experiences at Basel, see Thomas M. Izbicki, "The Possibility of Dialogue with Islam in the Fifteenth Century," in Nicholas of Cusa: In Search of God and Wisdom, ed. Gerald Christianson and Thomas M. Izbicki (New York: Brill, 1991), 175-183 at 179-180. Segovia himself suggests that the 'success' of Basel's negotiations with the Hussites supported his approach. See Mann, "Juan de Segovia," 88; Roth, De gladio, 1:xlxli; and below, p. 21.

12 For a fuller discussion of this aim, see Wolf, "Juan de Segovia," 204ff.

13 See Mann, "Truth and Consequences." On this image, see Norman Daniel, Islam and the West: The Making of an Image (Edinburgh: University Press, 196o); and John Tolan, Saracens: Islam in the Medieval European Imagination (New York: Columbia University Press, 2002). Wolf notes that Segovia employs a "pejorative description of Muslims" already in one of his earliest works dating from 1427, see Wolf, "Juan de Segovia," 119. See also Roth, De gladio, 1:xxxi.

See Burman, Reading the Qur'an, 180, 186. 
on the trilingual Quran, this tension also shows itself in Segovia's 'plan'15 to foster debate between Christians and Muslims while simultaneously bemoaning the paucity of worthy Muslim interlocutors and decrying the supposed Muslim contempt for reason and aversion to disputation. ${ }^{16}$ In the words of a modern advocate of honest interreligious dialogue, Segovia often engages "not a real, but a projected other."17 And so we come to the text translated in this chapter.

Segovia's LMA is one of his 'late' works, probably composed after the Council of Basel (1449) but before November $1453 .{ }^{18}$ Although an ecclesiological treatise that seems to represent some modifications of Segovia's previous conciliarist views, ${ }^{19}$ the $L M A$ also contains numerous references to Islam and Muslims. ${ }^{20}$ The most extensive discussion of Islam appears in Animadvertencia 10, chapter 6. Rolf De Kegel has called this chapter the "earliest passage in Segovia's writings in which he treats Islam at such length." ${ }^{21}$ More importantly, De Kegel also notes that this passage contains the central themes of Segovia's

15 Wolf has rightly observed that Cabanelas overstated the coherence or systematic nature of Segovia's 'plan.' See Wolf, "Pleas for Peace," 65, n. 9.

16 These were, of course, traditional Christian criticisms of Islam. See, e.g., Daniel, Islam and the West, 123-124; and Mann, "Juan de Segovia," 85.

17 See David Tracy, Dialogue with the Other: The Inter-Religious Dialogue (Grand Rapids: Eerdmans, 1990), 4.

18 For a critical edition, see De Kegel, $L M A$ (see above n. 7). On the dating of this work, see De Kegel, $L M A$, 31-36. For more on the $L M A$, see Werner Krämer, Konsens und Rezeption. Verfassungsprinzipien der Kirche im Basler Konziliarismus (Münster: Aschendorff, 1980), 248-251; H. J. Sieben, "Basler Konziliarismus konkret (II). Der 'Liber de magna auctoritate episcoporum in concilio generali' des Johannes von Segovia," in Vom Apostelkonzil zum Ersten Vatikanum. Studien zur Geschichte der Konzilsidee, ed. H. J. Sieben (Paderborn: Schöningh, 1996), 157-95; Rolf De Kegel, "Johannes von Segovia und die verfassungsmässige Vereinbarkeit von Papst und Konzil," in Nach dem Basler Konzil: Die Neuordnung der Kirche zwischen Konziliarismus und monarchischem Papat, ca. 1450-1475, ed. Jürgen Dendorfer and Claudia Märtl (Münster: LIT Verlag, 2008), 45-66; and Thomas Prügl, "Herbst des Konziliarismus? Die Spätschriften des Johannes von Segovia," in Das Ende des konziliaren Zeitalters (1440-1450): Versuch einer Bilanz, ed. Heribert Müller (Munich: Oldenbourg, 2012), 153-174, esp. 159ff.

19 See Prügl, "Herbst des Konziliarismus," 159: "Am sichtbarsten änderte Segovia seine frühere Position im LMA."

20 For examples, see Madrigal, "Lex Christi," 350-355; and Wolf, "Juan de Segovia," 238. De Kegel, "Johannes von Segovia und die verfassungsmässige Vereinbarkeit," 63 also notes that about twenty citations from the Qur'an appear in $L M A$.

21 See De Kegel, $L M A$, 34: "Es ist die früheste Stelle in Segovias Schriften, die so ausführlich über den Islam berichtet." 
more detailed discussion of Islam in his subsequent correspondences and in his later tract De gladio divini spiritus in corda mittendo Sarracenorum. ${ }^{22}$ Others, too, have seen the significance of this chapter. ${ }^{23}$

LMA 10.6 is part of Segovia's larger argument that monarchy has always been and will always be the 'political' structure of the Christian church or polity (politia). ${ }^{24}$ In discussing the superiority of this monarchical structure as well as the general superiority of the Christian polity over other 'polities' (including Jewish, Muslim, and pagan), Segovia advances four reasons for Christianity's preeminence. ${ }^{25}$ From these, the fourth reason is that the Christian religion excels in its number of learned men. On this point, Segovia compares Christianity to both Judaism (10.5) and Islam (10.6), but he is especially interested in explaining why the Muslims lack learned men, despite their large population and their extensive political power. ${ }^{26}$

Such is the context and principal aim of LMA 10.6. This brief introduction to the appended translation cannot even attempt to address all the issues raised by this rich chapter. Nevertheless, I should like to offer four observations here.

First, while it clear that Segovia intends to criticize and denigrate Muslims in this chapter, he does not hesitate to criticize Christians as well. He accuses Christians, notably learned Christians, as well as Muslims and Jews, of hypocrisy, of preaching virtue but practicing vice (10.6.9). More significantly, he also suggests that Christians have been woefully remiss in explaining their faith to Muslims, and that this failure has plagued Christianity since the rise of Islam (10.6.6). One should not exaggerate its importance, but this self-criticism in the context of criticizing the 'other' is at least noteworthy. ${ }^{27}$

22 De Kegel, $L M A$, 34. See also idem, "Johannes von Segovia und die verfassungsmässige Vereinbarkeit," 63 .

23 See Meuthen, "Der Fall," 58 with n. 104; the articles by Santiago Madrigal cited above (n. 7) repeat arguments Madrigal first advanced in his book, El pensamiento ecclesial de Juan de Segovia (1393-1458): La gracia en el tiempo (Madrid: Universidad Pontificia de Comillas, 2004), esp. chap. 3; see De Kegel's own subsequent discussion in "Johannes von Segovia und die verfassungsmässige Vereinbarkeit," $5^{2-54}$; and Roth, De gladio, 1:xlii-xliii.

24 See LMA 10.1.1 (ed. De Kegel, 366-67).

$25 \quad L M A$ 10.2.2 (ed. De Kegel, 368).

$26 \quad L M A$ 10.5.5 (ed. De Kegel, 376).

27 Both these self-criticisms echo arguments apparently first made in his 1427 Repetitio de fide catholica. See Wolf, "Juan de Segovia," 122-124. Madrigal published an 'edition' of this Repetitio as an appendix to his El pensamiento ecclesial, 193-225. The corresponding passages are found in Madrigal, El pensamiento ecclesial, 223-224. Madrigal seems to have followed a different foliation from Wolf. Recently, Madrigal discussed a plan to re-edit this Repetitio. See Santiago Madrigal Terrazas, "Juan de Segovia y la transmisión de sus 
Second, Segovia seems especially fond of the four reasons he presents in this chapter as to why Islam has so few learned men (10.6.1-4).$^{28}$ In a somewhat modified form, these same four reasons, which echo traditional Christian criticisms of Islam, reappear in Segovia's letter to Jean Germain (18 December, $1455)^{29}$ and even more interestingly in the De gladio divini spiritus in corda mittendo Sarracenorum (1453-57). ${ }^{30}$ That Juan de Segovia recycled his own arguments is not news. ${ }^{31}$ Intriguing, however, are the varying ways in which he employed these arguments. In the De gladio, for example, Segovia sets his four reasons for the Sarracens' lack of wisdom and understanding (here sapientia and intellectus, not sapientes) within the context of Aristotle's discussion of masters and slaves, or rulers and ruled. ${ }^{32} \mathrm{He}$ concludes that, given their intellectual deficiencies and their indulgence of carnal appetites, Muslims are by nature better suited to be slaves than masters. ${ }^{33}$ This is not the place to pursue this matter further, but only to note that it merits more detailed investigation.

manuscritos: El ejemplo del "Liber de substancia ecclesie," in De la prima a la segunda "Escuela de Salamanca": Fuentes documentales y lineas de investigación, ed. M. A. Pena González (Salamanca: Universidad Pontificia, 2012), 43-53 at 50.

28 Briefly stated, these are: 1) their obsession with venery; 2) their emphasis on military training and warfare; 3 ) the deleterious effects of the warm climates they inhabit; and 4) their disdain for reasoned debate and for literary pursuits. I think both Madrigal, "Lex Christi," 354, and De Kegel, "Johannes von Segovia und die verfassungsmässige Vereinbarkeit," 53, somewhat misrepresent Segovia's fourth reason when they suggest that, in Segovia's view, Muslims are so occupied with the study of the Qur'an that they consequently neglect other studies. Apart from other problems with this interpretation, Segovia says quite clearly that Muslims do not merely neglect but actively disdain 'studia litterarum.'

29 See Mann, "Juan de Segovia," 85.

$30 \quad$ See Roth, De gladio, 1:358-386, esp. $366 \mathrm{ff}$. (= consideratio 18). I believe Prof. Roth was the first to notice this specific connection between the $L M A$ and the De gladio. See Roth, De gladio, 1:367, n. 26 .

For additional examples of this practice, see Jesse D. Mann, "The Historian and the Truths: Juan de Segovia's Explanatio de tribus veritatibus fidei," 2 vols. (Ph.D. diss, University of Chicago, 1993), 1:171, 270.

See Roth, De gladio, 1:364-366. Cf. Aristotle, Politics, 1252b-1255b. This seems to be a littlestudied instance of Segovia's use of Aristotle. On the general theme, see H. J. Sieben, "Aristotles bei Konstanzer und Basler Konziliaristen," in Vom Apostelkonzil zum Ersten Vatikanum. Studien zur Geschichte der Konzilsidee, ed. H. J. Sieben (Paderborn: Schöningh, 1996), 196-222 at 214-216.

33 Roth, De gladio, 1:366.120-126: "Quomodo autem Sarracenis natura magis servos quam dominantes esse conveniat, illis presertim, a quibus incepit secta, Machometus ipse omnifariam testis est, cum persaepe affirmet gentem, ad quam missus est, ineruditam et insciam esse legendi scribendive ac rudem, quin immo et scientiae incapacem, sed et 
Third, lest we forget that LMA 10.6 aims to emphasize the superiority of Christians over Muslims, toward the end of the chapter (10.6.13) Segovia asserts that the real leaders in many Muslim communities, including even the military leaders, are apostate Christians. In so doing, he seems to show some familiarity with the devshirme, the obligation to surrender Christian children to be raised as Muslims in Ottoman state service, often as Janissaries. ${ }^{34}$ To wit, Segovia speaks of the exalted status such 'apostates' have achieved in Muslim society, and describes the lengths to which some Muslim parents would go to have their own children included among these 'renegades.' Modern scholars have noted that recruits from the Christian levy did indeed obtain some of the highest offices in the state, and that Muslim parents grew envious of these Christian converts. ${ }^{35}$ Precisely how Juan de Segovia might have known about the devshirme I cannot at present say. And one cannot completely exclude the possibility that Segovia is here simply embellishing the polemical commonplace that the Muslim elite is secretly Christian, ${ }^{36}$ though this seems less likely. In any case, Segovia's point is clear enough: even in military matters, where Islam seemingly surpasses Christianity, there too the Christians are deemed superior to the Muslims.

My final observation does not pertain directly to LMA 10.6; however, it is germane to the theme of interreligious comparison that marks this entire chapter. Before undertaking his comparison of Christianity with Islam, Segovia had noted that there are some differences between Christianity and all other religions or 'polities' (including Islam) that render comparison impossible. One such incomparable difference is Christianity's 'end' ( finis). Accordingly, Segovia writes:

No attempt will be made to compare Christianity's manifold superiority in other matters where one cannot properly speak of 'superiority', since [Christianity] and the other religions (politiae) do not share a common

compendii gratia restringens se pro modo calamus alias explicare rationes commemorat dumtaxat notissimas cuilibet intueri volenti quattuor causas, quare Sarraceni a magnitudine deficiant sapientiae et intellectus..."

34 On the devshirme and the Janissaries, see V. L. Ménage, "Devshirme," in Encyclopaedia of Islam, 2nd ed. See also Godfrey Goodwin, The Janissaries (London: Saqi Books, 1997), esp. chap. 3; and Robert Elgood, The Arms of Greece and Her Balkan Neighbors in the Ottoman Period (New York: Thames and Hudson, 2009), 33. I owe to Rita George-Tvrtkovic and Christine Isom-Verhaaren the suggestion that Segovia may be alluding to the Janissaries here.

35 See Goodwin, Janissaries, 35; and Elgood, The Arms of Greece, 33.

36 On this view, see Tolan, Saracens, 252 (citing Riccoldo da Montecroce). 
ground. Such, for example, is Christianity's end, namely the attainment of eternal beatitude and direct vision of God. For, as was explained [above] in the fourth consideratio, no other society (societas) shares in this end. ${ }^{37}$

This may not be quite the same as saying extra ecclesiam salus nulla est, but it is not too far from a similarly exclusive view about salvation. Such a view of the way to salvation helps explain why, in $L M A$ 10.6.12, Segovia states that the goal of engagement with Muslims is "to endeavor to save their souls." 38 Just as ecclesiology is, for Segovia, ultimately a matter of soteriology, ${ }^{39}$ so too is dialogue with Islam ultimately a matter of the salvation of souls. No wonder, then, that Segovia puts this important discussion of Christian-Muslim relations in one of his mature ecclesiological works-a work in which he also suggests that a general council could be an appropriate place for Christians and Muslims to discuss their differences. ${ }^{40}$

37 LMA 10.2.2 (ed. De Kegel, 368 ): "Nec fit comparacio de aliis multis preeminenciis eius, in quibus proprie non dicitur excellere, cum cetere policie non sint illorum participes, pote de fine, qui est eterne assecucio beatitudinis in faciali Dei visione constitute. Huius quippe finis, prout in quarta consideratione fuit explanatum, experte sunt cuncte alie societates." Segovia's terminology is notably not uniform here (politia, societas, lex, etc.).

38 LMA 10.6.12 (ed. De Kegel, 382): “... operam dare ad salvandas eorum animas.” Here again, Segovia's position is reminiscent of views expressed in his Repetitio de fide catholica. See Anne Marie Wolf, "Juan de Segovia and the Lessons of History," in In the Light of Medieval Spain: Islam, the West and the Relevance of the Past, ed. Simon R. Doubleday and David Coleman (New York: Palgrave, 2008), 33-52 at 33.

39 On this point, see Jesse D. Mann, "Refuting the Pope: Comments on Juan de Segovia's Gloss on the Bull Etsi non dubitemus," Annuarium Historiae Conciliorum 37 (2005): 323340, esp. 340.

$40 \quad$ See LMA 11.37.3 (ed. De Kegel, 605). For the context of this suggestion, see Sieben, "Basler Konziliarismus konkret," 189; and De Kegel, "Johannes von Segovia und die verfassungsmässige Vereinbarkeit," 62 . For an alternative, but not wholly unrelated view on why Segovia treats Islam in this ecclesiological work, see Madrigal, "Lex Christi," 350-352. 


\section{Appendix \\ A Translation of Juan de Segovia, Liber de magna auctoritate episcoporum 1o. 6 (ed. De Kegel, 377-383)}

Four reasons are provided as to why there is not a multitude of learned men among the Saracens, which is connected to a discussion of how the law of Muhammad saps their strength with blindness.

(§1) The foregoing [chapter] has set out why the Jewish community has contributed, albeit in a limited way, to the support of the Christian faith with a certain multitude of learned men and books. [Now] the reasons must be explained why the Muslim community, despite its large numbers, is not brimming with learned men, or at least has very few. First of all, the most obvious reason is that the Muslims are excessively given to carnal desire. Acts of venery completely distract [their] minds from the height ${ }^{41}$ of mental reflection that is essential for and of great necessity to the growth of knowledge. Wherefore, as Jerome teaches, it is a salutary remedy for scholarly men "to love the science of Scripture in order not to love the vices of the flesh" (Ep. 125.11). The Saracens, however, have the liberty according to their law to take numerous wives; and, as many of them inhabit warm regions, they continuously devote themselves to erotic deeds or, to put it more aptly, to venereal passions. For not satisfied by intercourse with women, many of them burn "with desires for each other, men committing shameless acts with men" (Rom 1:27). Nor is this point undercut just because certain Christians, among whom there are many wise men, may also be charged with this [crime], since such ones are said to be very few, and they hardly dare to commit this outrage even in secret. Moreover, these Christians are not at all interested in wives so that, except to produce offspring, they are hardly said [even] to engage in intercourse. Those considered most learned are rarely or never accused of this terrible crime. But the Saracens, who have many children, burn greatly with that heinous crime and even permit public brothels of adolescent youths. Consequently, since they love vices of the flesh too much, they do not at all apply themselves to the study of Scripture. Book II of Maccabees recounts the story [that] impious Jason made use of this very evil, indeed, one might even say, diabolical stratagem [when] he tried to convert his coreligionists to the Gentile rite so that they might forget God's law and stray from all moral discipline. Under the citadel of Jerusalem he established a gymnasium, and "he put the noblest youths in brothels" (2 Mc 4:10, 12).

\footnotetext{
* I should like to thank Bernard McGinn and Tom Izbicki for their helpful suggestions. As will be evident, this translation is more literal than literary. 
(§2) Here is the second reason why the Muslims do not enjoy an abundance of learned men, a situation excused - indeed commanded — by their law. For among all the commands contained in the Qur'an one very frequently finds that good men are required to go to war, and the exhortations toward this end are quite numerous. Consequently, the Qur'an regularly reproves indolence and cowardice. We see, however, that certain [religious] orders that are trained to fight against infidels produce few literate men, while the Mendicant orders that were established to preach do [produce such men], since the training of the military orders was not geared toward knowledge, as was the case with the Mendicants, but rather toward military ends. Since, therefore, the religion of Muhammad so zealously incites Muslims to fight against Christians, whom they call 'unbelievers,' wanting to fulfill this commandment, the Saracens prefer to devote themselves to military training rather than to study. Their concern is not so much to abound in a multitude of learned men as in a multitude of [military] victories.

(§3) Furthermore, the nature of the regions where the Saracens dwell provides a clear indication [of] why there should be a lack of learning among them. For those regions are very hot and thus not so conducive to the study of sciences, while the regions where the Latins live are neither [very] hot nor very cold, but rather cool. For knowledge is gained by intense consideration that requires a collectedness of spirit; however, it is characteristic of heat to melt and of cold to break down. Thus, we know from repeated experience that in universities and schools, students who learn in winter rather than in summer succeed. The proof of this is that both in the time of the pagans and of the Christians, the vast number of books was not written by those residing in very hot places, but rather by those residing in cool places, with the exception of those areas that are near the coast and thus tempered by the coolness of the sea air. So we see that the Saracens who live among the Christians, although very few in number, have an aptitude for learning sciences provided they abstain from venery.

(§4) The final reason for the lack of learning among the Saracens, at least as regards the study of their law, [is] that being strong in numbers, they do not think it worthy to debate according to reason, and thus they do not so much neglect as contemn the study of letters. And this has been the case since the beginning of that sect. Consequently, by this very fact they show themselves [to be] devoid of truth. They are only willing to defend themselves with an armed multitude so that by means of that multitude they might defeat those whom they cannot overcome by reason.

$(\S 5)$ This defect of theirs in no small measure helps the Catholic faith. For if, like the Jews, the Saracens were willing to engage in debate, since they are so numerous, they would perhaps frequently change the minds of many faithful [into] thinking that they 
are on the side of truth. But since they avoid debate, they serve to strengthen the faith of Christians. They avoid debate when they come together with others [i.e., nonMuslims] not, as many believe, because their law so mandates-for the law of Muhammad in Surah 38 actually exhorts all men of laws (except the evil ones) to speak and dispute always with respectful words - but rather, Muslims avoid debate perhaps, nay rather undoubtedly, because their priests fear being confuted. Whoever carefully observes the Muslim religion will find that it is not so much malice as blindness that causes it to deviate so strongly and fundamentally from the law of grace. To wit, Islam asserts that Christians believe that the Son and the Holy Spirit are like companions or consorts of God. It asserts that the Son and Holy Spirit are 'participants' in deity and that [Christians] worship them [as such]. If this were in fact the case, then Muslims would rightly ridicule Christians as they [now] do, calling them 'worshipers of the companions or participants of God.' For they say that none but the one sole God should be worshiped [and] that sect thinks that Christians worship Father, Son, and Holy Spirit as if they were three essentially different gods.

(§6) Now in truth it would appear that much work must be done so that the Christian faith might be cleared of this abominable calumny. For the failure to expound the doctrine and to demonstrate that such was not the case was greatly detrimental from the beginning of that diabolical sect that blasphemes the Christian faith to such a degree, because they are unable to understand that the three persons [of the Trinity] are one and the same God. Note, however, that I have said 'unable' not 'unwilling.' Indeed, it greatly appears from the tenor of that religion ${ }^{42}$ that smallness of intellect and dullness of mind have been largely responsible for its propagation.

$\left(\S_{7}\right)$ And just as they failed on account of blindness in regard to the mystery of the Trinity, so too [they have failed] in regard to the mystery of the Incarnation. For they consider it impossible that God should have taken on human form. They do not know or do not want to declare that God took on not the person but rather the nature of humanity.

(§8) Likewise, the book of the Qur'an, which makes mention of this point more than fifty times, speaks so equivocally and variously that it frequently contradicts itself; and as proof that [their] religion is true, it expressly alleges that all the devils of hell could not compose so much as even a single one of its very complicated chapters.

42 Here, as elsewhere, I have translated lex as 'religion' rather than 'law' when context and sense suggest and justify such a translation. 
(§9) In the same way it speaks most confusedly about the Gospel, the books of Moses, of David, and of the other prophets because, rightly wanting to defend their religion, they hate the light. Actually, one can understand these four books clearly, indeed concretely, through learned reasoning. All Muslims, to the extent that they are learned in their law, indeed the more learned they are, the more clearly [they] understand that their religion lacks any basis in authority or reason. What happens to them, just as Augustine says of the philosophers in his book Devera religione (1.1), is that they understand one thing and do another. Indeed, the philosophers understood that those 'gods' worshiped in the temples were not really gods; but not wanting to contravene the common error, they venerated them [anyway] along with the [entire] population. Even the Apostle did not pass over this crime in silence, saying that they "suppress the truth of God in wickedness" (Rom 1:18). The learned among the Jews were not free from reproach of this type. For while preaching that one should not steal, they themselves stole; and while preaching to others that one should avoid adultery, they themselves committed adultery; and while [supposedly] abhorring idols, they themselves committed sacrilege. In general: those who instructed others did not instruct themselves. Of course, many learned men in the Christian religion are entangled in that vice. As the Apostle testifies, their minds and consciences are befouled, because, trusting themselves in [their] words, they deny God in [their] deeds. Thus they become abominable and disbelieve "and reject every good work" (Ti 1:15).

(§10) Surely, therefore, if such is the case among learned Saracens, [then] as the old proverb says, "believe the one with experience in the matter." Those who wish to meet and debate with Muslims must have at the ready reasons and arguments [for] why, with the coming of the law of grace, the law of Moses had to cease, and [why] the one law does not support the other but rather constitutes an obstacle to its observance. That most evil sect glories in this, namely that it has mixed together the law of Scripture and the law of the Gospel. Properly speaking, it has made a pastiche, preserving neither law but rather destroying both. Thus, once one has established the incompatibility between the law of grace and the law of Scripture, [i.e.,] the law of the Gospel and of Moses, by this fact the bond of that mixture disappears, and the one wanting to sustain it sees its foundation crumble. [Then], because he believes that these two laws were given by God, unless he is quite shameless, he necessarily must adhere to the law of the Gospel. And for the Muslims, who find the rites and condition of the Jews especially odious, it is no mean step, once they understand these things, to prefer living under the law of the Christians after they have heard an explanation of the truths that especially belong to the catholic faith from which they shrink, thinking [Christians] to be worshipers of the Son and Holy Spirit, not as if one with God the Father, but as if companions or associates in deity. 
(§11) Moreover, they also judge it to be impossible that God's son should be the son of Mary. They are unable to understand that great love by which "God so loved the world that he gave his only begotten Son so that all who believe in Him should not die but have eternal life" (Jn 3:16). Likewise, they misunderstand the Passion, thinking only in human terms that a father whose son has been condemned to prison would beseech the judge and offer him gifts and even kiss his hands, as they say, that the judge might free his son. They therefore consider the Christian faith stupid for affirming such things. Additionally, since Christianity involves eating Christ's body and drinking His blood, the Muslims ridicule the Christians for 'eating' their God and for forgiving men's sins and for other such things they consider absurd. But this misapprehension is due solely to a lack of understanding. For when one explains the mysteries of faith to them, they are stupefied and, conscious of their ignorance, they admire those who explain these mysteries. Consequently, anyone having honest discussions with them has profound pity on the ignorance of the Muslims that derives from their lack of thorough instruction, as well as on their blindness that seeks in so many things to be illuminated.

(§12) There is one point we cannot pass over in silence, namely that for three hundred years now numerous Christian armies have made expeditions against the Muslims both by land and by sea. They have achieved very little in regard to the intended goal of liberating the Holy Land and of exterminating Muhammad and his followers. Rather, these expeditions have greatly harmed the Christian religion. And today, with the Muslims so numerous and the way of war so difficult, it would perhaps not be useless nor ill-advised to try another way to win them over. For an enemy is not always conquered by the sword, but often by many other means, and this would be the greatest victory: to endeavor to save their souls. Have we not seen in our own days that many great armies of the faithful had little success against the Hussites and other heretics of the kingdom of Bohemia, who were going around devastating with fire and sword? But when they agreed to the church's exhortation to examine their differences in a public debate, it was noteworthy that they ceased the persecution they had previously inflicted on the neighboring territories on account of their errors. Nor did they afterwards boast, as they had previously done, about their widely disseminated letters as if those letters contained the truth and everyone else had erred. ${ }^{43}$

43 Segovia is referring to the debates with the Hussites at the Council of Basel. On these debates, see Johannes Helmrath, Das Basler Konzil 1431-1449: Forschungsstand und Probleme (Cologne: Böhlau, 1987), 353-372; and more recently, Gerald Christianson, "Church, Bible, and Reform in the Hussite Debates at the Council of Basel, 1433," in Reassessing Reform: A Historical Investigation into Church Renewal, ed. Christopher M. 
(§13) We will put off for another time the discussion of the method the church should employ in its debates with the Saracens regarding the aforementioned four points, namely: the mystery of the Trinity, the mystery of the Incarnation, the book of the Qur'an, and of the Gospel and the other books of the sacred canon commemorated therein and similar matters. Would that this may come to pass in our days! However, it was relevant to our purpose to have shown that the community of the faithful exceeds all others in its number of learned men. As the Philosopher teaches, wisdom is the greatest of all joys in the world (cf. Aristotle, Ethics 10). And as Solomon testifies, "wisdom is better than arms" (Ws 6:1). Regarding military strength, which is inferior to wisdom, it is well known that, when one compares the faithful Christian people with the Muslim people in the neighboring regions, apostate Christians constitute the strength and core of their army such that these apostates rule over them. Furthermore, in certain Muslim domains only a renegade Christian can become the ruler. For reliable sources have observed that in numerous Muslim principalities no one except renegade Christians assumes the captainship or [any] offices of higher rank. Wherefore the more astute Muslims who want to comply with this custom have their children baptized so that these children may be judged worthy of such offices. Then when the children are older, they induce or coerce them to abjure the Christian faith so that they might be considered apostate Christians. Thus, when they die, their children succeed to the posts that their parents held. Accordingly, the Muslims themselves attest that [even] in regard to this military strength those marked by the name of Christ are superior.

(§14) Of the other three aforementioned points in which the Christian religion surpasses all others, it is not necessary to say much. They follow directly from this, given the presupposition regarding the number of learned men. For given that the greatest number of learned men is found among the [Christian] faithful, and given that by nature everything strives to preserve itself, in order that this multitude of learned men should not diminish, there should be an increase in the number of universities, libraries, and books, as well as an expansion of the Latin language, which is useful to all these ends. Now given this excellence, namely the multitude of learned men by which the faithful people outshines all others, it is quite clear that the community of God's people was most rightly established from the beginning of the world and will continue in this way forever. As the Philosopher teaches, "it is the mark of the wise man to [establish] order" (Aristotle, Metaphysics 1). "It is in the very nature of wisdom that powerfully links one end to another to order all things well" (Ws 8:1) and give order to the things of the universe, to declare [them to be] from God and to show this to others.

Bellitto and David Zachariah Flanagin (Washington, DC: Catholic University of America Press, 2012), 124-148. 
Whence, since [the Christian religion] outstrips all others in its number of learned men, anyone can very clearly see that the Christian community is most rightly established over all others and indeed that, by virtue of its abounding wisdom, this community is the measure and order of all others. For in any genus whatsoever, that which is first is the measure of the other [elements], and surpasses them in this virtue that the others might imitate in a proportional manner but never fully attain. 